\title{
Factors influencing the use of e-learning facilities by students in a private Higher Education Institution (HEI) in a developing economy
}

\author{
Sunday C. Eze ${ }^{1 凶}{ }^{1 凶}$, Vera C. A. Chinedu-Eze ${ }^{2}$, Clinton K. Okike ${ }^{1}$ \& Adenike O. Bello ${ }^{1}$
}

While research into the adoption of e-learning in Nigeria has mainly focused on its use in public Higher Education Institutions (HEls), there is still a lack of research on factors affecting students' use of e-learning in private HEls in Nigeria. This study, therefore, explores factors influencing the use of e-learning by students in private HEls in Nigeria using TechnologyOrganisation-Environment (TOE) framework. We use a data collection method encompassing semi-structured interviews with 15 students from L-University drawn purposefully from the Landmark directory and a hybrid thematic analysis to analyse the data. Our findings reveal that technology-related factors (ease of use, speed accessibility and service delivery), organisation-related factors (training support and diversity), environment-related factors (attitudes of the users) and impact-related factors (learning experience, skill development, academic performance, and degree of engagement) influence the students' adoption of elearning facilities. We develop an extended TOE framework that integrates the impact context which considers the students likely expectations if these facilities are fully adopted and implemented. The study also unveils techniques that may accelerate the development of e-learning structure in private HEls and which could provide the opportunity of assisting communities of learners to adopt and use e-learning facilities regularly.

\footnotetext{
${ }^{1}$ Department of Business Studies, Landmark University, Omu-Aran, Nigeria. ${ }^{2}$ Department of Agribusiness and Management, Michael Okpara University of Agriculture, Umudike, Nigeria. ${ }^{凶}$ email: sundayeze2010@gmail.com
} 


\section{Introduction}

- he continual advancement in information technology has provided the HEIs with the opportunities to advance their teaching and research since these institutions deliberately depend on rapid information to become proactive (Agostini and Nosella, 2020; Eze et al., 2018; PR Newswire, 2019; Chuang et al., 2009; Awa et al., 2011; Maldonado et al., 2011; Economides and Jeziorski, 2017). Most HEIs try to cope with the state-of-the-art Information Communication Technology (ICT) (Eze and Chinedu-Eze, 2018) by making an enormous investment on IT platforms to remain competitive despite the alarming rate at which such applications advance in the modern Information Systems (IS) marketplace (Al-Gahtani, 2016; Bhuasiri et al., 2012; Zhang et al., 2010; Kotler, 1984; Abdulhamid et al., 2017; Eze et al., 2019).

Technology creates an avenue for socio-economic changes (Bates and Jenkins, 2007; Saheed et al., 2019). It is a force that leads to destruction in human existence (Chuang et al., 2009) mainly in the educational sector where teachers move from a stage of providing basic teaching aids to an environment where teaching is interactive. Although most HEIs in Nigeria has embarked on several programs that promote the adoption and use of Information Technology (IT) for both online and classroom teaching (Eze et al., 2018; Aboderin, 2015), the IT-related innovations such as e-service have transformed the HEIs completely from the traditional approach of teaching and learning to more contemporary approach (Naqvi, 2007; Bhuasiri et al., 2012; Hu and Hui, 2012; Al-Gahtani, 2016). According to Wang (2009), E-learning consists of IT-based innovations in education with a pool of technology-enabled platforms that provide alternative and innovative learning methodologies compared to the conventional learning methods (Bates and Jenkins, 2007).

E-learning in this paper refers to computer-based (e.g., digital videos, tablets, projector, operating systems) learning process which links digital content, system-based administrations and mentoring support and aid in the interaction of students and teachers (Eze et al., 2018; Abdulhamid et al., 2017; Zhang et al., 2010; Arghya et al., 2020). Private HEIs have adopted some elearning tools which provide the institution and students with increased interest in achieving higher performance through the development of new human competencies. Education and personal development have become a major interest for institutions and people which lead to increase in life-long learning. People now update their knowledge and skills to remain relevant (Mason and Rennie, 2006; Eze et al., 2013; Dubé et al., 2017). Also, the number of e-learning platforms is on the rise resulting in several research materials and papers (Wu et al., 2012; Franco and Garcia, 2018) for solving students' educational needs. Although elearning is an alternative to blended learning or conventional classroom teaching methods, it has witnessed a rough path. M (Johnson et al., 2008). The resistance to the e-learning system adoption by most HEIs is attributed to poor awareness, poor management support, poor funding, inadequate infrastructures, abysmal management commitment to interactive knowledge environment (Eze et al., 2018; Prause, 2019; Bukhari, 2010), limited resources and awareness (Markus and Robey, 1998), inadequate training and manpower (Bhuasiri et al., 2012), inadequate internet facilities (Allen and Seaman, 2003; Abdulhamid et al., 2017; Okundaye et al., 2019) and the steady decrease in the Nigerian education budget from 55.19 trillion budgeted for education in the last 10 years to 3.90 trillion or 7.07 per cent (https://www.vanguardngr.com/2018/04/education-free-fall/).

However, e-learning is gaining ground across different areas. Elearning is a tool students in HEIs adopt to learn rationally regardless of time and space (Daukilas and Vaisnoriene, 2009; Nuryyev et al., 2020). E-learning helps create and develop human capabilities. For instance, if teachers and students in the private HEIs are better trained using e-learning tools for delivering lectures, they become more innovative (Loogma et al., 2012; Agostini, and Nosella, 2020). Also, the shift from conventional classroom learning to e-learning is an important transformation for both the learning model and HEIs (Saheed et al., 2019). This leads to innovative behaviour and attitude. Besides, some major innovation capabilities are required for effective exploitation of elearning (Hong et al., 2018). Learning may affect innovation positively and subsequently lead to higher education excellence (Jimenez-Jimenez and Sanz-Valle, 2011). E-learning systems can develop private HEIs that are open to learning. Therefore, in the implementation of an e-learning program within private HEIs, efforts should be made to create a transfer opportunity, since preceding studies (see Pineda-Herrero et al., 2011; Asongu and Le Roux, 2017) have shown that few HEIs offer the resources, time and opportunity to apply what the employees learned after attending e-learning courses. E-learning adoption and use by students in private HEIs is vital because it provides an opportunity to consider e-learning adoption and use by universities in the promotion of teaching. It offers students significant benefits such as increased access to learning opportunities, the convenience of time, and place, provide a greater assortment of learning resources, improves opportunities for learning by individuals and the emergence of more powerful intellectual tools. Khan, Pierre, Nuryyev et al. (2020) provide reflective and deep learning thoughts, offers students adaptive personalised e-learning as an important alternative to the one size fit all approach of online learning (Adeola et al., 2013; Arghya et al., 2020).

\section{Problem statement}

While e-learning has constantly been adopted and helped in the establishment of virtual universities in most western countries, only a few private universities in Nigeria completely carry out their academic activities through e-learning (Eze et al., 2018). The majority find it difficult to use e-learning, while to some, it is still a dream because of poor and weak technological infrastructure. Also, most research in this area has focused on public HEIs (Anene and Odumuh, 2014; Dubé et al., 2017). These studies centred on difficulties, problems and prospect of e-learning and issues relating to the availability of e-learning facilities (Anene et al., 2014; Sezgin, 2016). However, its adoption and/or use by students in private HEIs in Nigeria have been essentially understudied. Little is still known about the factors that shape the adoption and use of e-learning facilities by students in Private HEIs and frameworks that serve as a guide to private HEIs in adopting and utilising e-learning facilities (Bukhari, 2010; Hu and Hui, 2012; Franco and Garcia, 2018) by students in Nigeria are needed. This is because conventional methods of teaching and assessments in these institutions are regularly practised while elearning is yet to be fully implemented (Singh and Hardaker, 2014; Ahmed, 2010; Dubé et al., 2017) and used by students. Although some private HEIs are trying to embrace e-learning completely by committing huge resources in acquiring these facilities, many have failed to accomplish this task because of the rate of illiteracy and inadequate funding (Aboderin and Kumuyi, 2013) making its adoption and use rather low.

The study, therefore, explores the factors influencing the adoption of e-learning facilities by Private HEI students of LUniversity. This is driven by the fact that L-University is one of the first private HEIs that have invested heavily on e-learning facilities in Nigeria. Exploring these factors will help private and public HEIs in becoming more tactical and proactive in taking decisions that will assist students in adopting and utilising these 
facilities regularly. Also, this study is vital because many studies in Nigeria have focused on issues relating to the availability of elearning facilities, difficulties and the prospects of e-learning mostly in public HEIs (Anene et al., 2014; Economides and Jeziorski, 2017) while, the factors that shape e-learning adoption and use by students in private HEIs in Nigeria have been essentially understudied.

The study adopted a qualitative method because the majority of technology adoption and use studies are based on quantitative methods involving hypothesis testing (see Williams et al., 2009; Silva, 2007). According to Williams et al. (2009), about 65 per cent of studies in this area adopt quantitative approaches while methods, like interviews, secondary data analysis, mathematical modelling were rarely deployed. This approach will help diversify research in terms of methods used since the majority of the research in this field has continually deployed quantitative approaches, while other methods such interviews, thematic analysis, sentimental analysis, inductive case study or grounded theory approach have been largely ignored. The paper is structured as follows: First, it reviews and analyses the literature. Secondly, it presents the overall research approach and data analysis process; thirdly it highlights the finding and presents the proposed conceptual framework. The last section highlights the conclusions, discusses the implications, limitations and future research.

\section{Literature review}

The concept of e-learning. E-learning is defined as digitally permitted and technology-facilitated learning devices that use a digital camera, personal computers (PCs), digital videos, tablets, projector; OHP, software, operating systems which aid in the interaction of students and teachers (Markus and Robey, 1998; Olojo et al., 2012; Eze et al., 2018). It includes other applications that support learning from a distance or face to face with the help of PC (Markus and Robey, 1998). E-learning has moved from learning from the conventional method to contemporary driven, synergistic, customised and adaptable learning method involving learners', facilitators and instructors (Falana, 2015). The traditional method of learning was considered teacher-focused, while the learner-focus is centred on technologies which assist learners in distribution and getting contents frequently. E-learning covers basic and synergistic PC supported scholarship process and evaluation methods that use innovative approaches and applications to advance teaching and research (Mahahusudhan 2008; Eze et al., 2018), empower students and teachers to share learning contents produced in a consistent structure (Nkanga, 2007; Naidu, 2006; Markus and Robey, 1998). E-learning is a vital strategy that every institution should embrace into the present learning and education technique for both the students and community-oriented learning (Falana, 2015; Sloan et al., 2014; Olojo et al., 2012). According to Markus and Robey (1998), mentoring and learning are often done by students using the PC as a technology-facilitated learning process using digitally transported contents, and coaching support.

Liverpool et al. (2010) noted that using e-learning as a strategy to execute learning contents and components in Nigeria's HEIs makes it dynamic for both teachers and students as a medium of learning of the materials. According to Kajetanowtez and Wierzejewski (2010), e-learning is a dynamic technique that aids the improvement of self-study, constant testing and assessments which provokes genuine examination of educational development and intermittent accomplishment. Literature review suggests that e-learning provides valuable result on the accomplishments of learners. This technology innovative approach assists learners in becoming innovative (Garrison and Anderson, 2003; Eze et al., 2018).
Some of the major benefits of e-learning to institutions, facilitators or instructors are that it saves time, helps in projecting the image of the institution, encourages knowledge advancements of staff, improves how teaching and learning are carried out and makes adaptation more predominant.

According to Richmond, there are links between educational programs and ICT. Technology can impact on learning through a presentation, the use of information utilising devices, use of educational modules and the use of online reference books and electronic diaries. However, the use of e-learning as a teaching methodology has witnessed massive adoption in developed countries where several institutions see e-learning activities as a means to grow and improve their institutions. Furthermore, the way and manner in which the methods of teaching are changing in the 21 st century are alarming. The integration of technologies as a way of life due to the emergence of the internet has also changed how teaching is conducted in HEIs especially in developed economies. Today, the combination of e-Learning strategy and traditional face-to-face learning strategy (blended learning technique) has been embraced. While this technique or method caters specifically for individual needs of the learner compared to the conventional classroom teaching approach because the students may have unique learning styles, this approach is not prominent in Nigeria.

The Development of e-Learning and the extent of adoption and utilisation by Private HEIs in Nigerian. The emergence of elearning in Nigeria dated back during the introduction of telecommunication in 1886 by the colonial masters between Lagos and the colonial office in London to convey information and receive feedback (Ajadi et al., 2008). All government offices in Lagos in 1893, had access to telephone service for easy access, communication and feedback. This service was later extended to other parts of the country. Nigeria has witnessed a lot of changes in the telecommunication sector since its emergence. These changes include the takeover of the sector by the Nigeria Telecommunication (NITEL) till in the '90s when the Federal Government of Nigeria began the liberalisation policy of the telecommunication industry. Several private telephone service providers such as Mtel-NITEL, Econet, MTN and Globacom (Glo) Nigeria were licensed to provide General System for Mobile Services and subsequently, other companies were licensed to provide internet services in Nigeria. This led to improved access to the internet by Nigerians. For instance, as of 2006, many people connected to the internet through the information superhighway broadband (Ajadi et al., 2008).

The most common type of e-learning adopted and used by private HEIs in Nigeria was in the form of lecture notes on CDROM which can be played at any time the students want. The major challenge associated with this method is that the number of students per computer in which these facilities are available is un-interactive as compared to when lectures are been received in the classroom (Ajadi et al., 2008). Some private HEIs introduced intranet facilities. However, the major challenge with the intranet was poor maintenance due to continuous power problem coupled with the high cost of running and maintaining the generating set. Majority of students go to public cyber café and because of the number of students who are engaged on the internet, there was a problem of low bandwidth resulting in lack of multimedia interactivity. Despite the importance of elearning adoption and use in Nigeria, some Universities and other higher institutions do not have access to these facilities at all. Although the literature suggests that a substantial number of private HEIs in Nigeria have commenced the development of elearning centres, Salawudeen (2006) argues that these centres 
are mainly built as a web office without bearing in mind major facilities that makeup e-learning centres.

Although Nigerian academics have shown interest in the adoption of e-learning facilities in HEIs however, the inability of the students to develop the capacity and information to utilise elearning facilities adequately even when the facilities are there (Eze et al., 2018) is a huge challenge. Also, students are faced with problems amidst their studies; poor teaching techniques in students' educational programs, restrictions of students from operating the e-learning (Ostund, 2005), poor vision and procedure in implementing e-learning, (Oguzor, 2011), lack of dedication and skills required for the implementation of elearning and dissatisfaction witnessed during the development of e-learning facilities (Kizito and Bijan, 2006; Eze et al., 2018). Despite these challenges facing e-learning in Nigeria institutions, some private HEIs have developed the e-learning facilities. However, the number is still very low compared to the western world because of the location of most HEIs, poor electricity supply and low bandwidth. Although, many private HEIs have started setting up their ICT centres for internet services alone without actually taking into consideration other components of elearning centre (Ajadi et al., 2008) which might enhance the quality of teaching and learning in those institutions.

Presently, the number of private higher institutions in Nigeria is almost out-numbering their public counter-parts and the rates at which these institutions adopt modern e-learning facilities are impressive. This may suggest that private HEIs in Nigeria may be IT-driven compared to public HEIs. However, because these private HEIs are small in terms of capacity and are being financed by individuals or group of individuals who often are the owners, they have better operating agility and make decisions relating to elearning adoption faster than public HEIs (Eze et al., 2018). Arguably, these characteristics may justify why private HEIs may be ahead of public HEIs in e-learning adoption. Many private institutions in Nigeria may be at the frontline of leveraging from elearning because many are well funded compared to public institutions. This may also affect the degree at which students in the private HEI use e-learning when compared to those in public institutions (Eze et al., 2018). Although private HEIs may be better situated in the use of e-learning however, financial challenges in Nigeria hardly allows either the private or public HEIs to hugely exploit the full advantages of e-learning. The students in private institutions may be more willing to adopt and use e-learning facilities because of the goals and vision of the owners.

However, several factors may influence the adoption and utilisation of e-learning in private HEIs.

In Nigeria, education is exceptionally underfunded. The educational budget by the Federal government in the last ten years has represented an average of 5.17 per cent compared to other Sub-Saharan Africa countries (Nwokolo et al., 2017). While private HEIs are not capable to self-finance the institutions and most of the proprietors do not have the financial capability to fund the university for a very long time, the investment on ICT for education purposes be it private or public HEIs is very low. The funding of e-learning projects, training and retraining of teachers, development of software packages, the development and maintenance of electrical reducing stations and provision of technological infrastructure are difficult to accomplish due to poor funding (Ajadi et al., 2008; Nwokolo et al., 2017).

HEIs largely depend on electrical power to carry out their daily activities. However, the current electricity supply in Nigeria is very low, unstable and not available in many rural areas where the majority of the students reside (Ikediugwu, 2008). Most private HEIs cannot afford to operate on generator sets at all times as electricity is needed for the computer to function and enable students to be able to connect to the internet.
The basic facilities/infrastructures are needed for institutions to be IT-driven. By standard, every lecture classroom is expected by the National University Commission (NUC) to acquire the necessary physical facilities in information communication technology such as computer system, telecommunication system and multimedia system (Ololube et al., 2006), projector, whiteboards, satellite, broadband links, DVD, and computers (Nwokolo et al., 2017), computer hardware which includes microprocesses, storage devices, input devices (Anowor, 2010). However, in most private institutions, such facilities are not adequate and this largely affects teaching and learning.

Most curricula used by HEIs to meet the basic needs of elearning is inadequate. Otuka (2010) noted that the existing subject syllabuses do not have any e-learning opportunities designed and integrated into it. Developing and designing the uses of e-learning into the curriculum should be a key priority and part of the national strategy. Both teachers and students need exposure to online educational training, awareness of the diverse learning strategies and when they need to be applied. However, this has affected so many lecturers as most of them still adopt a teachercentred approach. Many still do not know how to use e-learning facilities for their teaching (Otuka, 2010). Hence, most curricula adopted by HEIs need to be designed for both teachers and students to improve their skill and know-how in ICT. Hence, the government should develop a strategy to ensure that e-learning is embedded into the core subject areas to enable academics and students exchange knowledge and improve the quality of teaching and learning across the private and public HEIs.

Previous studies on e-learning in HEIs in Nigeria. Anene et al. (2014) studied the problems and prospects of e-learning in University of Abuja Nigeria, by examining the accessibility and availability of e-learning resources to unravel students' adoption and use of e-learning platforms during studies. Their findings revealed that a major challenge in the use of ICT is poor and inadequate infrastructure. It was revealed by Nigerian students that the university lacks the fund to build adequate e-learning library domain. As such students do not partake in online seminars, online examination, and discussion with lecturers due to limited bandwidth (Eze et al., 2018). This had resulted in the repeated strikes by the Academic Staff Union of Universities in Nigeria (ASUU) in a bid to force the government to correct abnormalities and increase the annual budget for the education sector (Eze et al., 2018).

Further, Chiaha et al. (2013) on the other hand investigated the e-learning facilities students have access to in public institutions, the degree at which students access the facilities and the factors that hamper students from gaining access to e-learning facilities. The outcome of the study shows that over $41 \%$ of the students can access e-learning facilities. However, what most students have access to is the e-mail accounts and factors such as unsatisfactory electric power supply, and poor network connections hinder access to e-learning facilities (Chiaha et al., 2013; Eze et al., 2018).

Abdulhamid et al. (2017) investigated the elements of perpetuation intention to use e-learning among students in public universities in Nigeria drawing on Technology Acceptance Model (TAM) and Expectancy Disconfirmation Theory (EDT) with a total of 760 sample size. The study investigated the relationship between elements of perpetuation intention to use elearning among public university students in Nigeria. The result revealed that accomplishment is a determinant of perpetuation intention to use e-learning which is based on observed simplicity of use, endorsement of using e-learning, internet self-efficacy and observed excellence. The study found these variables as essential determinants of perpetuation intention of using e-learning. 
Nwokolo et al. (2017) reviewed the impact of e-learning on education and training in Nigeria's public tertiary educational institutions and discussed the impact of e-learning technologies, factors affecting its full adoption such as power shortage, lack of technical manpower and high cost of computer hardware acquisition. The study mentioned the prospects of its full implementation to the institutions and recommended the way forward. They recommended that the Government of Nigeria both at the state and federal level should invest in ICT manpower development and infrastructure. They also noted that HEIs should invest in alternative and renewal energy sources and teaching staff to provide learning resources in the cloud for timeless access.

Atsumbe et al. (2012) examined the accessibility and use of elearning structures in one of the Nigerian public universities. The study specifically looked at the adequacy of e-learning infrastructures for teaching and learning; the capacity of the e-learning facilities to teaching, learning and interactions among teachers and students, as well as the factors that hinder the utilisation of elearning facilities. The outcome of the findings showed that there are poor facilities specifically directed towards teaching and learning rather most facilities were channelled towards administrative use, although students and lecturers have laptops and internet facilities that are not used for teaching.

Aboderin and Kumuyi (2013) investigated the problems and prospects of e-learning in developing and implementing curriculum in secondary schools in Ondo State, Nigeria. Their study focused on the accessibility of e-learning tools in implementing curriculum, the degree at which they are applied by teachers, strategies and prospects of e-learning in secondary schools. The findings revealed that tools available for e-learning are limited and the few available are not satisfactorily utilised. The researchers recommend that government should organise training and retraining of teachers on how to use the facilities and in turn teachers should regularly use it with the students during teaching and research activities. This finding was consistent with the work of (Aboderin, 2015).

Although the literature suggests that a substantial number of works have been done on e-learning adoption in Nigeria, most studies have focused on difficulties, problems, prospect and issues relating to the availability of e-learning facilities mostly in public HEIs (Anene et al., 2014; Eze et al., 2018) while its adoption and use by students in private HEIs in Nigeria have been essentially understudied.

Technology organisation environment (TOE) framework. The study adopted TOE Framework. The theory was invented by Tornatzky and Fleischer (1990) and emerged from the field of organisational psychology. The TOE is the practice by which organisations accept and implement technological inventions that are influenced by the technological perspective, organisational perspective, and the environmental perspective (Eze et al., 2019).

The technological perspective encompasses the internal and external expertise that are significant to the organization. Technology perspective extends to the internal and the external benefits of technology aimed at increasing the output and the operational efficiency of the organization. It also includes the internal variables associated with the expected performance of the technology that has been considered before the implementation and the advantages or benefits of the technology. Liao et al. (2003) note that the experiences acquired either internally or externally by the firm encourages innovation, and institutions often look at the changes brought by innovations that shape the organization positively (Baker 2012). Several research work (e.g., Alshamaila et al., 2013; Ramdani et al., 2013; Zhu et al., 2003; Markus and
Tanis, 2000; Grandon and Pearson, 2004; To and Ngai, 2006) have adapted elements linked to technology contexts such as compatibility, perceived affordability and relative advantages. These variables have been proved to shape IT adoption and theoretical direction for many academic work in HEIs.

The organization perspective comprises business rivals, macroeconomic perspective, and the regulatory background, size, scope, and management structure, degree of centralisation, formalisation, and human resources (Tornatzky and Fleisher, 1990; Eze et al., 2018). For this study, organization context means conditions of the firm such as employee capability and management sustenance which influence the adoption of new technology (Baker, 2012). For the environment context to be successful, the management must ensure that they interconnect the roles of the new technology with the overall organization strategy (Madukua et al., 2016). Also, the organization context looks at how well the leadership at the management level works hand in hand with the departments to ensure that the overall objective of the organization is achieved. An organization that allows its employees to take initiatives from different ranks and files across the organization makes adoption decision less stressful. Studies (see Thong 1999; Ramdani et al., 2013; Gutierrez et al., 2015; Abdulhamid et al., 2017) have also investigated issues shaping e-learning adoption and use drawing on the organization perspective such as fulfilment, perceived employee acceptance, top management support, size, and scope.

The environment perspective is linked to competition, business practice, the government impact on the organization, trading partners, industry structure, location of the business, and globalisation (Mehrtens et al., 2001; Chau and Tam, 1997; Nguyen et al., 2015; Tornatzky and Fleischer 1990). The environment perspective comprises the internal and external elements that influence the adoption of IT (Andries and Debackere, 2006). The capabilities of HEIs to compete through the analysis of the internal environmental elements shape the adoption and use of e-learning facilities. Several studies (see Oliveira and Martins, 2010; Nguyen 2009; Ramdani et al., 2013; Mehrtens et al., 2001) have adopted elements relating to the environmental context which have been discussed widely in literature.

Tornatzky and Fleischer (1990), noted that these three elements (i.e., technological context, organisational context and the environmental context) present both limitations and opportunities for technology adoption and use. These three elements influence the way HEIs see the need to implement fresh e-learning technology. Rui, noted that the TOE framework is a useful analytical tool to examine and understand the drivers and inherent characteristics of e-learning applications associated with a firm's adoption. The TOE framework has also been adopted by a wide range of adoption studies (see Alshamaila et al., 2013; Lian, 2014; Maclennan and Van Belle, 2014; Ramdani and Kawalek, 2008; Ruivo et al., 2014; Weng and Lin, 2011; Madukua et al., 2016; Eze et al., 2018) and shows pragmatic flexibility in explaining e-learning application in HEIs.

Justification for using the TOE framework. Specifically, TOE framework was used in this study because TOE framework incorporates the environment context neglected by Innovation diffusion theory (IDT) propounded by Rogers (Oliveira and Martins 2011; Madukua et al., 2016). The TOE framework has also been considered as a more enriched (Alshamaila et al., 2013) framework to adopt in this study because it can incorporate a wider range of factors and extended ones that may shape the adoption of e-learning facilities by students in Private HEIs. Also, the TOE framework may be suitable for this study because HEIs 


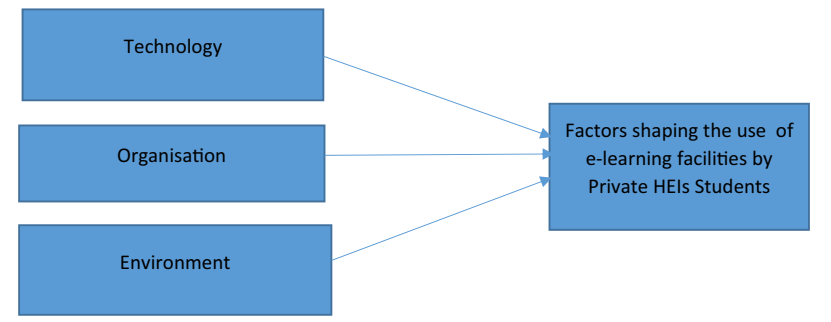

Fig. 1 Analytical framework for the study. This depicts the analytical framework for exploring factors shaping the use of e-learning facilities in a private HEI. The three boxes at the left side show the contexts under which these factors were explored. Thus they form the basis for the exploration of the factors shaping the use of e-learning facilities in this study.

are corporate entities with structures (e.g., physical facilities and learning) and functions (academic leadership, professional development, technological training and development and general higher education) which may unveil a wider range of factors associated with technology, organization and the environment that may shape the adoption and use of e-learning facilities in private HEIs. The analytical framework in Fig. 1 below forms the basis for the exploration of the study.

\section{Methodology}

Given that qualitative methods help to explain phenomena been studied in greater detail (Silva, 2007; Lee, 2003; Elliot and Loebbecke, 2000) and help to stress the discovery and explanation of people's experiences, the approach was adopted. This approach differs from a quantitative approach that focuses on testing variables and confirming the findings using a confirmatory statistical technique (Silva, 2007). While most studies (see Choudrie and Dwivedi, 2005; Orlikowski and Baroudi, 1991) have mainly adopted experimentation, case studies and survey methods in this area, little have deployed qualitative approach (see Choudrie and Dwivedi, 2005). This research used a qualitative approach to bridge this gap and to explore factors shaping the use of elearning facilities by students in private HEIs in Nigeria. The descriptive research design was adopted because the research is exploratory and involves the use of semi-structured interviews (Eze et al., 2018).

The population of the study consists of L-University students in the College of Business and Social Sciences (CBS-90), College of Science and Engineering (CSE-100) and College of Agricultural Sciences (CAS-50), between the levels of 200 and 500. Hence, the unit of analysis is at the individual level. Since the study involved people (students), data were collected at the individual (student) level. Since qualitative research focuses on the discovery and explanation of the participant's real-life experiences, the study adopted a purposive sampling technique in a bid to select units of analysis that will help the researcher to achieve the objectives of the study (Schultze and Avital, 2011). Out of 70 students conveniently selected for the study, 15 students agreed to be interviewed (see interview profile in Table 1). The bases for selecting these 15 students are in threefold: (a) they must have undergone an e-learning training organised by the university in the last one year (b) They must have been engaged in the e-learning activities of the university at least in the last one year. (c) They must have used some e-learning facilities available in the university. The instrument used for data collection was semi-structured interview questionnaire which consisted of a minimum of 10 questions that the respondents were asked to proffer answers to. The key questions asked during the interviews were: What is your department and college? As a student, have you been engaging in

\begin{tabular}{|c|c|c|c|c|}
\hline Interviewees & College & Level & Gender & Age \\
\hline A1 & CBS & 100 & Female & $18-25$ \\
\hline A2 & CBS & 100 & Female & $18-25$ \\
\hline A3 & CBS & 400 & Female & $18-25$ \\
\hline A4 & CBS & 300 & Female & $15-18$ \\
\hline A5 & CBS & 200 & Female & $18-25$ \\
\hline A6 & CSE & 200 & Female & $18-25$ \\
\hline A7 & CSE & 200 & Female & $18-25$ \\
\hline A8 & CSE & 300 & Male & $18-25$ \\
\hline A9 & CAS & 400 & Male & $18-25$ \\
\hline A10 & CAS & 400 & Male & $18-25$ \\
\hline A11 & CAS & 100 & Male & $18-25$ \\
\hline A12 & CSE & 100 & Male & $18-25$ \\
\hline A13 & CSE & 400 & Male & $18-25$ \\
\hline A14 & CAS & 200 & Male & Above 25 \\
\hline A15 & CAS & 400 & Male & $18-25$ \\
\hline
\end{tabular}

the e-learning facilities of the University? If yes, why? If not, why not? Can you say that the e-learning facility in the university is adequate? Why or why not? Describe what you found exciting about the e-learning facilities available in the university. Are there factors that hinder you from engaging with the facilities at all times? What are they? And please explain them. Describe the benefits associated with the use of those facilities. As a student, in general, describe the technology, organisation and environmental factors that influence your adoption of e-learning facilities in your University.

It is important to note that the main questions asked for the study were based on TOE frameworks. Questions and probe questions were asked based on each element of the TOE framework. Out of the 15 interviewed participants, 5 each from the three colleges of L-University agreed to be interviewed. Before the interview, a written letter requesting permission to be interviewed, where and when they wanted the interview to take place, as well as confidentiality issues were addressed. Before the commencement of the interview, the interviewees were informed about the reason and purpose of the interview. Also, consent was sorted in using an audiotape recorder. The interview which was scheduled for $45 \mathrm{~min}$ per interviewee lasted between $45 \mathrm{~min}$ and $1 \mathrm{~h}$.

Table 1 below depicts the interview profile A1, A2,...A15 represent the respondents or the interviewees, College of Business and Social Sciences(CBS), College of Sciences and Engineering (CSE) and College of Agricultural Sciences (CAS) were the three colleges in L-University.

\section{Data analysis}

Thematic analysis. According to Lacey and Luff (2001), there is no quick technique in qualitative analysis, instead, research of this nature is interpretive and subjective and the investigators are closely involved in the process. Although there are several methods in analysing qualitative data and no one method is the best. The approach one chooses is often based on certain criteria such as the research questions, objectives of the study, and scope of the research (Lacey and Luff, 2001). This research adopts thematic analysis. Thematic analysis is an approach that involves searching, identifying, analysing and reporting themes that are significant to the phenomenon being studied (Braun and Clarke, 2006; Giola et al., 2013). Because of the complex nature of qualitative studies Braun and Clarke (2006), argued that thematic analysis should be considered as the primary approach for qualitative analysis because it provides core skills for diverse approaches for a qualitative study. The flexibility nature of 
qualitative approach offers different ways of analysing data. Thematic analysis was adopted in this research because it constitutes a step by step process that assists the researcher in transforming qualitative information into qualitative data which help in generating codes and themes during the process for easy interpretation of findings that results in a more comprehensive understanding of the phenomenon (Boyatzis, 1998). Figure 2 below shows the process involved in the data analysis. Specifically, the researchers adopted the hybrid-approach of thematic analysis. This technique was adopted because codes were generated from the elements of the TOE framework, as well as the empirically driven code (impact) that emerged inductively. This approach was important because it helped in coding the raw data which help the themes to emerge in each category. This assisted in

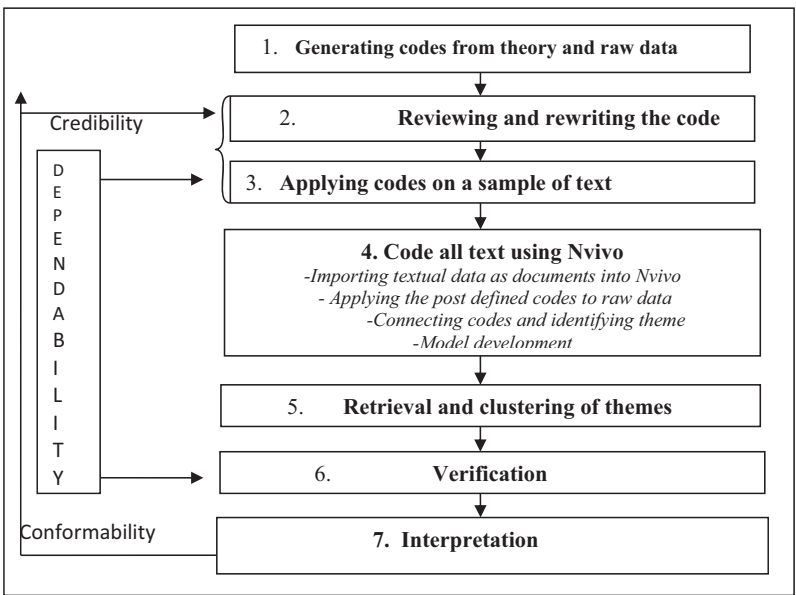

Fig. 2 Data analysis process. The data analysis process comprises of seven stages. At stage one codes were generated from theory and raw data. Stage two, the codes were reviewed and re-written in simpler terms. Sample of data was applied to the codes, followed by a readability test to ensure that all the codes are credible and applicable to subsequent raw data in stage three. At stage four, all the raw data transcribed either from the unstructured or semi-structured interview was imported into NVivo This aid the easy analysis and management of the huge data transcribed. Data were retrieved from NVivo and were conceptually clustered at stage five. At stage six, Inter-rater reliability of the entire data coded using percentage agreement was conducted which enabled several colleagues to rate the quotes against the codes and themes that emerge. Validated codes were further analysed and interpreted in stage seven. The data analysis process is part of the research design which reveals how data were analysed, verified and reported. checking the credibility and dependability (see Miles and Huberman, 1994) of the data. Figure 2 below consist of seven stages of the data analysis process.

Stage 1 and 2. At this stage, the concepts of technology, organisation and environment which had been developed previously from the literature were adopted. An empirically driven code (impact) that emerged from raw data during the preliminary analysis of the first four interviews (see stage 3 of the data analysis process) was also used in the study. The definitions and description of these theoretical codes were written in simpler form using a code name, the definition of the codes and how to identify themes associated with each code. These became the bases for categorising the raw data. The guide for coding the raw data is depicted in Table 2.

Stage 3. To ensure that the codes-technology, organisation and environments generated from theory and empirically driven code (impact) would apply to the raw data, in Stage 2, the first 4 transcribed interviews were coded manually into pre-defined and post defined categories. The researchers subsequently ascertained the reliability to ensure that all the codes are credible and applicable to subsequent raw data. Following the preliminary coding exercise, our colleagues who are experts in this area were contacted via writing and presented the codes and quotes who related both the pre-defined and post-defined codes to the categories to ascertain their reliability. The result of the reliability analysis shows a score greater than 70 per cent benchmark proposed by (Miles and Huberman, 1994).

Stage 4. At this stage, all the raw data transcribed either from the unstructured or semi-structured interview was imported into NVivo. NVivo software was adopted to facilitate the analysis because of the huge data involved. This aid the easy analysis and management of the huge data transcribed. NVIVO is software used in qualitative data analysis.

Stage 5. At this stage, data were retrieved from NVivo and were conceptually clustered (See Table 5).

Stage 6. Since reliability and validation in qualitative research is always an ongoing process, the researchers carried out other reliability and validity checks. These include presenting the codes and quotes to experts in this area who compared the quotes against the codes and themes. Therefore, Inter-rater reliability of the entire data coded using percentage agreement (Boyatzis, 1998) was conducted which enabled several colleagues to rate the quotes against the codes and themes that

\section{Table 2 Practical guide for coding the data.}

\section{Codes names Definitions}

Technology

Technology context include those internal and the external technology variables that impact private HEls student adoption of e-learning facilities

Organization Organisation context include resources that impact private HEls student adoption of e-learning facilities

Environment Environmental include factors that impact HEls, teachers and private HEls student adoption of e-learning facilities within the environment

Impact Impact expectancy refers to anticipated benefits associated with e-learning adoption by private HEls students

\section{Descriptions}

This is indicated when respondents mention that e-learning facilities are assessable. easy to use, provide comfort, speed, and the level of service delivery to the people etc.

This is indicated when respondents mention that training facilities for e-learning are satisfactory, and e-learning facilities can assist students in carrying out other activities.

This is indicated when respondents mention the manner (attitude) of users (teachers, students and HEls) etc.

This is indicated when respondents mention that experience, improvement in skills or development of skill, and improvement in academic performance etc. 
emerged. The codes and quotes were presented to two experts initially contacted via writing who compared the quotes against the codes. These experts rated the quotes against the codes and themes that emerged. This approach often required absence or presence judgments by the coders (Boyatzis, 1998). The reliability analysis for the scope of the study shown in Table 3 below revealed over 70 per cent which suppressed the 70 per cent benchmark by (Miles and Huberman, 1994).

Stage 7. Validated codes were further analysed and interpreted. The data analysis process in Fig. 2 is part of the research design which reveals how data were analysed, verified and reported.

\section{Table 3 Reliability analysis results.}

Factors shaping the use of e-learning facilities by private HEls students

Per cent agreement from the two Judges (0.96) $96 \% \quad(0.89) 89 \%$

\section{Findings}

Tables 4 and 5 show the codes, themes and the supporting shreds of evidence. The study adopted theory-driven thematic analysis in identifying the codes, analysing and clustering of similar supporting shreds of evidence across cases that emerged as themes. The presentation of the findings was drawn from both the narratives of the participants, codes, themes that emerged from the raw data and the relevant literature.

Framework on Factors shaping the utilisation of e-learning facilities by Private HEI Students in L-University. Figure 3 below shows the conceptual framework that reveals the factors influencing the utilisation of e-learning facilities by Private HEI Students. These factors were coded and classified based on the theoretical codes-Technology, organisation and environment, as well as the one empirical code-Impact which emerged inductively from the raw data during coding. The exploratory and the explanatory nature of the framework and the factors associated with the framework are based on narratives of the interviewed participants, the codes and the literature (Eze et al., 2018). These factors are discussed below.

Table 4 Codes, themes and supporting cases.

\begin{tabular}{|c|c|c|c|}
\hline \multirow{2}{*}{$\frac{\text { Code }}{\text { Technology }}$} & Themes & \multicolumn{2}{|l|}{ Total supporting cases } \\
\hline & Ease of use & $A 1, A 2, A 3, A 4, A 5, A 6, A 7, A 8, A 9, A 10, A 11, A 12, A 13, A 14, A 15$ & $15 / 15$ \\
\hline & Speed & $A 1, A 4, A 5, A 6, A 7, A 10, A 12, A 13, A 14, A 15$ & $10 / 15$ \\
\hline & Accessibility & $A 2, A 5, A 6, A 7, A 9, A 11, A 12, A 13, A 14$ & $9 / 15$ \\
\hline Total supporting cases & $A 1, A 2, A 3, A 4$, & A7, A8, A9, A10, A11, A12, A13, A14, A15 & $15 / 15(100 \%)$ \\
\hline \multicolumn{4}{|c|}{ Analysis by Colleges using total supporting cases } \\
\hline CBS & $\mathrm{A} 1, \mathrm{~A} 2, \mathrm{~A} 3, \mathrm{~A} 4$, & & $(100 \%)$ \\
\hline \multirow[t]{2}{*}{ Organization } & Training & $A 1, A 2, A 3, A 4, A 6, A 7, A 8, A 10, A 13, A 15$ & $10 / 15$ \\
\hline & $\begin{array}{l}\text { support } \\
\text { Diversity }\end{array}$ & $A 1, A 2, A 3, A 4, A 5, A 6, A 7, A 8, A 9, A 10, A 11, A 12, A 13, A 15$ & $15 / 15$ \\
\hline Total supporting cases & $A 1, A 2, A 3, A 4$, & A7, A8, A9, A10, A11, A12, A13, A15 & $14 / 15(93 \%)$ \\
\hline \multicolumn{4}{|c|}{ Analysis by Colleges using total supporting cases } \\
\hline Environment & $\begin{array}{l}\text { Attitudes of } \\
\text { the users }\end{array}$ & $A 3, A 5, A 4, A 7, A 9, A 8, A 10, A 14$ & $8 / 15$ \\
\hline Total supporting cases & $A 3, A 4, A 5, A 7$ & $A 10, A 14$ & $8 / 15(53 \%)$ \\
\hline \multicolumn{4}{|c|}{ Analysis by Colleges using total supporting cases } \\
\hline CBS & A3, A4, A5 & & $60 \%$ \\
\hline CSE & A7, A8, & & $40 \%$ \\
\hline CAS & $A 9, A 10, A 11, A$ & & $80 \%$ \\
\hline \multirow[t]{3}{*}{ Impact } & $\begin{array}{l}\text { Learning } \\
\text { experience }\end{array}$ & $A 1, A 7, A 9, A 10, A 11, A 12, A 15$ & $7 / 15$ \\
\hline & $\begin{array}{l}\text { Skill } \\
\text { development }\end{array}$ & $A 1, A 2, A 4, A 8, A 9, A 11, A 14$ & $7 / 15$ \\
\hline & $\begin{array}{l}\text { Academic } \\
\text { performance }\end{array}$ & $A 3, A 6, A 7, A 8, A 10, A 13, A 14$ & $7 / 15$ \\
\hline
\end{tabular}




\section{Table 5 Codes, themes and sample supporting shreds of evidence.}

\begin{tabular}{|c|c|c|}
\hline Code & Themes & Supporting evidence \\
\hline \multirow[t]{5}{*}{ Technology } & Ease of use & $\begin{array}{l}\text { "One of the ways I can access my course materials is through e-learning and easily interact and get feedback from } \\
\text { lecturers even when I am in the hostel". (A1) the stress of going to the class at all time is reduced since I can get } \\
\text { materials easily online and study on my own sometimes." (A14). } \\
\text { "It is stress-free within the comfort of my own bed". (A15) }\end{array}$ \\
\hline & Speed & Are the facilities quick, fast and user-friendly. (A4) \\
\hline & & $\begin{array}{l}\text { I think e-learning facilities is fast and simple to use. It is a link for a cordial relationship with our teachers because of } \\
\text { the facilities aid quick feedbacks. (A7). } \\
\text { Its quicker, and it had made us trust them because of the quality of the facilities. (A12) }\end{array}$ \\
\hline & Accessibility & $\begin{array}{l}\text { "We use it regularly because you can see what you are doing or what the teacher is doing and it is easily accessible } \\
\text { despite where you are". This promotes interrelationship and creativity as students. (A2) } \\
\text { "One can assess and engage himself with the assignments given by the teachers promptly". (A5) } \\
\text { "Easy and accessible to all of the students thereby helping them to meet deadlines such as assignments given by the } \\
\text { tutors". (A13) }\end{array}$ \\
\hline & Service delivery & $\begin{array}{l}\text { "The facilities are there for us at all times, however, sometimes the internet is not stable". (A.5) } \\
\text { "The poor internet and intranet services sometimes make the usage less utilised". (A 8) } \\
\text { "The major issue is that although the facilities are in school, we normally have an issue with poor internet services } \\
\text { This along affects its use". (A12) }\end{array}$ \\
\hline
\end{tabular}

Organization Training support "There are some facilities that are new to us, we still need some training". (A3)

"The training for some of the new facilities is not adequate". (A7)

"Although we are a small institution, we often train. This may depend on the time". (A13)

"What time is required for the school to train us on the facilities? If it is going to take too much of our time as students we may not use it". (A2)

Diversity "Can these facilities help us do other things apart from downloading lecture materials from the platform? The more diverse they are, the more we students will like to utilise it". (A5)

"I am always using these facilities because it allows me to download materials on the platform discuss with my teachers and also watch the study clips sent to us". (A9)

"I use it for different things". (A13)

Environment Attitudes of the users

"Sometimes some lecturers, especially the older ones, do not like using it to upload their lecture materials. This affects my using the facilities negatively". (A3)

"I don't see myself using it all the time because some teachers do not want to embrace the technology" (A7)

"Some lecturers are not using it and this affects us as well". (A14)

Impact Experience

Skill development

Degree of engagement

Academic performance "..... I get the lecture note from most of my lecturers before or immediately after the lecture, this makes me prepare

"based on my past experiences, it is difficult for me to use the facilities because some lecturers do not upload the lecture note until the exam period". (A1)

"I must tell you the truth, yes, the facilities are there but I have a bad experience because teachers most time are not willing to use it so I can see the notes and assignments on the platform. It is dissatisfying". (A9)

"I cannot rely on it because of the poor internet". (A11)

"It promotes interrelationship and creativity as students". (A1)

"Before I came here, I was not using such. I have learnt a lot of reading skills using the facilities". (A4)

"I can now use the facilities to create a lot of reading and learning chart" and how to create PowerPoint slides". (A9) for tests and exams ahead of time which improved my grade". (A3)

"My performance has slightly improved last semester because I download some of the lecture materials immediately after the lecture so that I can revise when I get to the hostel". (A14)

"It does depend on us students to use it, but if all lecturers are engaged with these facilities, we do not have an option than to use it regularly". (A10)

"It is a two-way thing, if our teachers use it regularly by posting their lecture notes and other clips on the platform, we too must also engage with it". (A15)

\section{Discussion}

\section{Technology}

Ease of use. Ease of use in this context is the capacity of the students to master the e-learning facilities without undergoing regular training. Drawing on the analysis, the finding revealed that most students in the private HEIs are eager to use the e-learning facilities introduced by the University because these facilities are used in teaching and learning among teachers in delivering lectures with little or no technical complexities during learning (Eze et al., 2018). Because of how friendly the facilities are, it was revealed by students that they feel relaxed using the facilities both within and outside the study areas. This was echoed across cases:
"One of the ways I can access my course materials is through e-learning and easily interacts and gets feedback from the lecturers even when I am in the hostel. It is really easy to use". (A1)

"It is because you can easily access materials, ask questions from the lecturers and they will reply even when movement is restricted" especially at night". (A7)

"The stress of going to the class at all time is reduced since I can get the materials easily online and study on my own sometimes". (A14) 


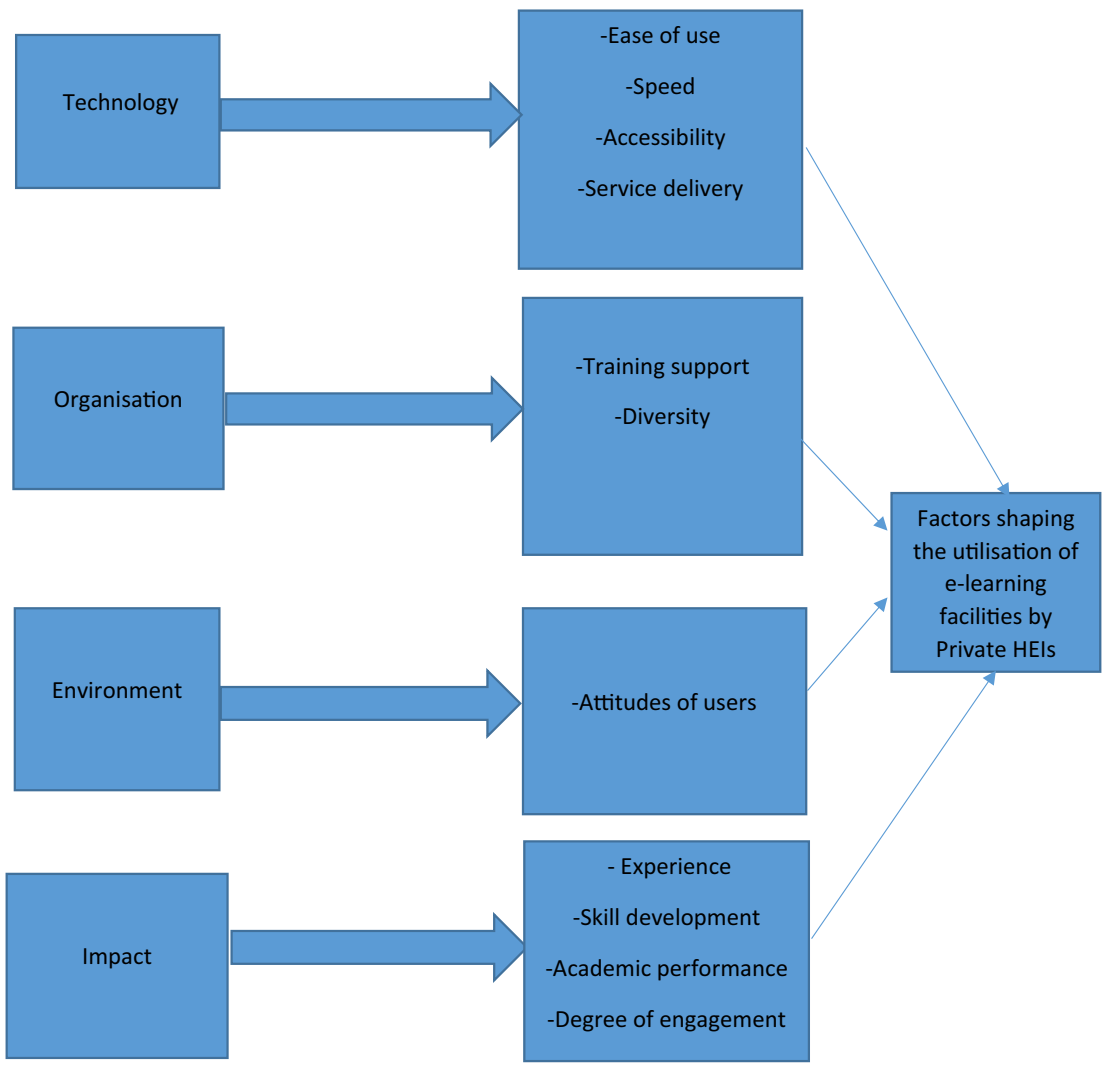

Fig. 3 Framework on Factors shaping the utilisation of e-learning facilities by Private HEls Students. The conceptual framework revealed factors influencing the utilisation of e-learning facilities by Private HEI Students. These factors were coded and classified based on the theoretical codesTechnology, organisation and environment, as well as the empirical code-Impact that emerged inductively during coding. The exploratory and the explanatory nature of the framework are based on narratives of the interview participants, codes that emerged and the literature.

"It is stress-free; I can also use them within the comfort of my own bed". (A15)

The finding implies that because of how simple the facilities are, students appreciate what was taught in class; they can access and retrieve lecture materials online at any time instead of waiting or looking for the hard copies of the lecture materials. This finding is consistent with Aboderin (2011) and Aboderin (2015) they found that the use of e-learning facilities makes teaching and learning very interesting and easier to deliver. Also, e-learning improves teaching through the provision of improved research information, ease, improves the quality of teaching, and enhances group learning (Amedu et al., 2014; Al-Gahtani, 2016; Economides and Jeziorski, 2017).

Speed. Speed is defined as the capacity of the e-learning facilities to produce or deliver the required results envisaged by students seamlessly and fast. Most of the interviewed participants were of the view that if the e-learning facilities would help them download materials as quickly as possible, receive lectures online and submit the assignments swiftly on the platform without any form of interruption or delay, such would trigger the usage at all times. This was similar to what the participants mentioned:

Are the facilities quick, fast and user-friendly (A4).

I think e-learning facilities are fast and simple to use. It is a link for a cordial relationship with our teachers because of the facilities aid quick feedbacks. (A7)
It's quicker, and it had made us trust them because of the quality of the facilities. (A12)

Several studies (e.g., Fitzgerald and Kenny (2003); Gholami et al. (2009); Gangwar et al. (2015)) also found out that the speed at which IT applications produces results within an organizational arrangement often lead to trial and utilisation of such applications(Hong et al. (2018); PR Newswire (2019); Saheed et al. (2019). The particular finding is also in line with some of the comments made by participants. A6, A10, A13, and A14

Accessibility. Accessibility reveals the extent to which the elearning facilities are made available to students. It was widely perceived by the participants that if the facilities are not restricted to some area, but extended within and outside the campus, such facilities would be constantly used. In line with the findings of, Sezgin (2016), Aboderin and Kumuyi (2013), and Anene et al. (2014) the ability to continuously access the progress of students' tests or continuous assessments results on e-learning platforms is important because it aids the usage by students: Similar assertions were made across cases:

"We use it regularly because you can see what you are doing or what the teacher is doing and it is easily accessible despite where you are. This promotes interrelationship and creativity as students". (A2) 
"It is easy to access. One can engage himself with the assignments given by the teachers promptly". (A5)

"Easy and accessible to all of the students thereby helping them to meet deadlines such as assignments given by the tutors". (A13)

This finding implies that students are satisfied with the facilities because they can access the facilities regardless of their location at any given time, and the intention to engage with the facilities regularly are higher compared to granting them limited access or location. Similarly, Nwokolo and Anyachebelu (2012) noted that the level of e-learning facilities would be fully utilised if these facilities are provided and regularly accessible. This finding is also consistent with the work of (Falana, 2015).

Service delivery. Service delivery in this context is the extent to which the facilities (e.g., internet and intranet) aids the use of elearning and are provided regularly. The analysis revealed that although the university to a large extent has these e-learning facilities however, poor internet and intranet connectivity frustrate most students in using these facilities. This was mentioned by participants:

"The facilities are there for us at all times; however, sometimes the internet is not stable". (A5)

"The poor internet and intranet services sometimes make the usage less utilized". (A8)

"The major issue is that although the facilities are in school, we normally have an issue with poor internet services. This has been affecting its use". (A12)

Internet is an important component that facilitates the use of elearning facilities (Song, 2003; Xu et al., 2011; Agostini and Nosella, 2020; Arghya et al., 2020). Availability of internet facilities facilitates the upload of lecture notes, assignments, playing of business communication teaching videos online and enhances teaching method. Similarly, Eze et al. (2018) noted that the internet enhances the usage of e-learning facilities and activates the users from being mere prospects to adopters.

\section{Organisation}

Training support. Training support in this context has to do with institutions ability to engage teachers and students with the elearning facilities to ensure that they master the usage and application over time. However, observations showed that both students and teachers were not adequately trained or developed in terms of its application. This greatly affects the use of the elearning facilities;

"There are some facilities that are new to us, we still need some training". (A3)

"The training for some of the new facilities is not adequate". (A7)

"Although we are a small institution, we often train. This may depend on the time". (A13)

"What time is required for the school to train us on the facilities? If it is going to take too much of our time as students we may not use it”. (A2)

It was discovered that the reason why students are not adequately trained is that the university does not have adequate skilled personnel to train both the students and teachers even when some of the students especially the newly admitted students do not have the requisite skill and know-how to use the facilities. This is consistent with the findings of Nbina et al. (2011) which established that many teachers and students do not know about ICT facilities and thus, shy-away from utilising them for teaching activities. Similarly, Asogwa, (2011) found that one key challenge for using e-learning is lack of requisite skills because most of them have not been trained to understand, operate and apply elearning packages successfully (Eze et al., 2018; Asongu and Le Roux, 2017; Ciechanowski et al., 2019). Therefore, L-University should conduct regular training for all parties that engage with the facilities.

Diversity. The use of e-learning facilities has made most institutions' information intensive. Institutions no longer rely on one particular information regarding a particular e-learning facility but also embrace diversity in terms of its functionalities within on and off classroom (Singh and Hardaker, 2014; Dubé et al., 2017; Sloan et al., 2014). Several respondents think that they will engage in e-learning if such facilities allow them to engage in several activities while using the facilities. This was highlighted thus;

"If I am well informed that these facilities can help us do other things apart from downloading lecture materials from the platform? The more diverse they are, the more we students will like to utilize it”. (A5)

"I am always using these facilities because the information I got has helped me know that it can allow me to download materials on the platform, discuss with my teachers and also watch the study clips sent to us". (A9)

"I use it for different things because I am well informed of its functions". (A13)

In line with the above finding, Boland and Tenkasi (1995), Falana (2015) and Aboderin (2015) established that students tend to engage more with e-learning facilities if it assists them in carrying out several activities on the platform.

\section{Environment}

Attitudes of the users. The attitude in this context is the behaviour of teachers and students in using the e-learning facilities. It is a key factor that shapes how students use e-learning facilities. Observations revealed that some lecturers especially the older lecturers do not like to use the e-learning facilities. Even the younger ones are lazy to prepare power points and upload the lecture materials on the platforms so that students can make use of the facilities to access the materials. Thus, lecturer's attitudes toward the use of e-learning facilities greatly affect the usage by the students: This was echoed across cases:

"Sometimes some lectures, especially the older ones, do not like using it to upload their lecture materials. This affects my using the facilities negatively". (A3)

"I don't see myself using it all the time because some teachers do not want to embrace the technology". (A7) "Some teachers are not using it and this affects us as
well". (A14)

"Some teachers and students can never change even when the technology is to assist in making their work easier". (A1)

The implication of this finding is the indisposition to change to the new method of computer literacy among lecturers and 
students. This is one of the major challenges facing both teachers and students in utilising e-learning facilities (Eze et al., 2018; Franco and Garcia, 2018; Asongu and Le Roux, 2017). Hence, if teachers constantly use the facilities to upload their lecture notes, PowerPoint presentations and assignments, it will positively affect the students' usage because they will also use the facilities (Gutierrez et al., 2015). Hence, there is a need for the mind-set of the lecturers to change to embrace these facilities which is consistent with the work of (Ilechukwu, 2013).

\section{Impact}

Experience. From the analysis, evidence revealed that most of the new students in the university particularly the experienced ones that have used the e-learning facilities at the initial stage of the admission process, greatly affected them when they started lectures at the University. While some were of the view that during the computerbased test for new intakes, they spent $3 \mathrm{~h}$ because the facilities were not working, other new students believed that lecturers were not using them and that affected the way they perceive the facilities:

"Before I gained admission into the university, I went on a 3 month eLearning training, so when the e-learning was introduced to us during my first year, it was not an issue". (A15)

"Based on my past experiences, it is difficult for me to use the facilities because some lecturers do not upload the lecture note until the exam period". (A1)

"I must tell you the truth, yes, the facilities are there but I have a bad experience because teachers most time are not willing to use it, so I do not see the notes and assignments on the platform. It is dissatisfying". (A9)

"I cannot rely on it because of the poor internet". (A11)

This finding implies that the experiences students have in the first few months at the university concerning using the e-learning facilities will greatly impact the user. This is consistent with the work of Kayisire and Wei (2016), Lian et al. (2014), and MacLennan and Van Belle (2014). From the analysis, it is believed that students would fully utilise the e-learning facilities if such facilities are available, functional, and often used by teachers to communicate and teach the students regularly (Zafar and Mustafa, 2017).

Skills development. Skill development is the capacity at which the e-learning facilities assist students to acquire new skills and improve their learning capacity (see Prause, 2019; Okundaye et al., 2019). Many students particularly those at the 300 and 400 level, during their interview, mentioned that the e-learning facilities have helped them acquire skills such as reading skills, creative skills, learning skills, communication skills and presentation skills via these facilities. This was echoed across cases:

\section{"It promotes interrelationship and creativity among students". (A1)}

"Before I came here, I was not using such. I have learnt a lot of reading skills using the facilities". (A4)

"I can now use the facilities to create a lot of reading and learning chart" and also learnt how to create a power points presentation". (A9)

Observation revealed that the development of skill by students was subject to how effective the university train the staff and students which is consistent with (Nuryyev et al., 2020; Napitupulu et al., 2018).

Academic performance. Academic performance is defined as the extent to which the e-learning facilities aid students' assessments, results, presentations and virtual interpretations. Most of the participants at 300 and 400 levels thought that their academic performances have improved over time since they fully engaged with the facilities as noted:

“..... I get the lecture note from most of my lecturers before or immediately after the lecture, this makes me prepare for tests and exams ahead of time which improved my grade". (A3)

"My performance has slightly improved last semester because I download some of the lecture materials immediately after the lecture so that I can revise when I get to the hostel". (A14)

Although few students at 100 and 200 levels are of the view that they have not seen much improvement or major impact of the elearning usage on their academic performance. The finding is consistent with (Al-Gahtani, 2016; Aboderin and Kumuyi, 2013). The reason being that they are still new and possibly learning how best they can utilise the facilities. This implies that the students' progress from one level to another, increases the chances to engage with the use of e-learning facilities (Asongu and Le Roux, 2017; Ciechanowski et al., 2019).

Degree of engagement. The degree of engagement is the extent to which efforts are made by both teachers and students to utilise the available e-learning facilities in the institution. Today, the number of higher institutions are enormous and competition is high (Amedu et al., 2014; Al-Gahtani, 2016; Economides and Jeziorski, 2017). And observation during the analysis shows that institutions that partner with other institutions create a good atmosphere for learning to take place. Secondly, it was also revealed that the extent at which both the teachers and students engage with the e-learning facilities create an enabling environment for teacher-students relationship and regular use.

"It does depend on us students to use it, but if lecturers are engaged with these facilities, we do not have an option than to use it regularly". (A10)

"It is a two-way thing, if our teachers use it regularly by posting their lecture notes and other clips on the platform, we too must also engage with it". (A15)

The finding implies that regular engagement of e-learning facilitates by teachers, staff and students create enabling environment among workgroups for better usage and adoption decision which is consistent with the works of (Ajadi et al., 2008; Aboderin, 2015; Nwokolo et al., 2017).

\section{Conclusion}

The study explored the views of students of private HEIs on the utilisation of e-learning facilities. More specifically, the research explored the factors that shape students' adoption and use of elearning facilities within the University and underpinned by the TOE framework. The research identified 12 factors that greatly impact on student's utilisation of e-learning facilities. Since the study was underpinned TOE and the themes that emerged were clustered based on TOE elements. From the findings, $100 \%$ of the participants revealed that technology-related factors such as ease of use, speed and accessibility and service delivery influence their 
usage of the e-learning facilities, while $93 \%$ of the participants indicated that organisations related factors such as training support and diversity shape their use of e-learning facilities. On the other hand attitudes of the users were linked to the environment and this accounted for $53 \%$ of the views of the participants, while the impact-related factors such as learning experience, skill development, academic performance and degree of engagement accounted for $93 \%$ of the participant's views. The implication is that private HEIs should constantly train both staff and students. More emphases should be placed on new students and staff to ensure that they use these facilities. The university should ensure that mentoring and monitoring of students is adopted on a weekly bases to ensure that students use them regularly and internet facilities should be provided. Furthermore, the university should endeavour to ensure there are regular technical infrastructures such as the internet and intranet access on the campus.

While all the participants across the three colleges were of the view that technology-related factors, organisation related factors, environment-related factors and impact-related factors influence the students' use of e-learning facilities, the degree at which these factors influence students' use of e-learning varies across colleges. The findings revealed that technology-related factors are strongly supported by the three (college) groups followed by organisation and impact-related factors, respectively. The least factor supported by the group is the environment-related factor. The implication of this is that factors that shape student's use of e-earning facilities are strongly linked to technology and organisation.

Although private HEIs have acquired to some extent several elearning facilities, the use of e-learning facilities in these institutions is still not encouraging. This is as a result of the attitude of the students and the technical know-how which may be one of the reasons that account for the low usage of e-learning adoption and use in most private HEIs today. From the analysis, there are some mixed feelings about the use of e-learning facilities by students across the university. Observation revealed that 100 to 200 level students were not at ease using the e-learning facilities either because they were new to the institution, and/or are trying to understand how the facilities are being used, while the 300 to 400 level students appear to be more exposed to the use of elearning facilities. The implication of this is that private HEIs need to ensure that students are trained and exposed from inception to the use of e-learning facilities available in the university to support students in their academic pursuit throughout their stay at the university.

Furthermore, it was revealed that some students have developed resistance to change because they are not used to the elearning facilities. Also, poor internet facilities, limited training as a result of poor knowledge of ICT facilities and lack of requisite skills were major challenges facing students.

Implications. For improvement to the academic performance of the students and the university community at large, the use of elearning facilities is no longer a decision of a few IT experts in the institutions rather it requires the participation of the entire university community involving various stakeholders including the students who substantially use the facilities. According to Eze et al. (2014), several persons within and outside the institution can shape and be shaped by e-learning adoption in the University and these people are the ones driving the adoption and usage of such facilities. The findings revealed that although L-University may have adopted a substantial number of these facilities, students are not maximising the usage because they are not part of the decision making process. For instance, in most Private HEIs where the funds are provided by the individuals (proprietors), decision making is made by few individuals without asking for the initiatives of those that use the facilities regularly. Hence, if the facilities are eventually procured some stakeholders particularly the knowledgeable ones may not use them. The adoption and use of policy by the University may require the attention of students and other stakeholders before decisions are made. Therefore, the study recognises the importance of individual factors in the adoption and effective use of the e-learning facilities which will improve the private HEIs by recognising the social dimensions of e-learning adoption and use such as the academic and professional goals, interest and needs, sources of work pattern and social network (Singh and Hardaker, 2014).

The framework developed using a hybrid approach of thematic analysis in this study may serve as a reference point for university management that may want to efficiently adopted e-learning facilities for student's use. The finding provided in the framework may guide the University management on the likely factors that might shape the regular usage of e-learning facilities by the students, pros and cons of such exercise and the challenges management of university may encounter. Also, the framework which deployed the TOE framework as the theoretical underpinning has extended TOE by incorporating the impact context which was empirically driven. The extended TOE framework implies that the adoption and use of e-learning facilities may not only be shaped by the technology-related factors, organisation related factors and environment-related factors but also, the impact of such facilities to the betterment of the overall university community and most especially the students who are regular users of these facilities. Therefore, this research provides an understanding of issues associated with the usage of e-learning mechanism in private higher education institutions. It reveals practices that may shape the fast growth of established e-learning structure (Singh and Hardaker, 2014; Eze et al. (2018) in private universities.

A substantial number of studies on e-learning adoption and use research have focused mainly on quantitative approaches while others approach such as interviews, grounded theory, thematic analysis have been largely neglected. This study draws on the qualitative method particularly the use of interviews and a hybrid approach of thematic analysis to explore the factors influencing the use of e-learning facilities amongst private HEIs students. This is a conceptual way of analysing, gathering and clustering themes into most suitable categories. The study, therefore, created a consciousness of diversifying e-learning adoption research in terms of method by using different approaches. This approach helps in making the findings and description clearer, as well as the themes or code, developed and it is useful to other researchers that may want to further the research.

Limitations for further studies. One of the challenges of qualitative research is normally the size and sample used. In this work, the researchers acknowledged that the size and sample in this study are limited. The limitation requires caution in generating the findings in this work. We challenge future researchers to validate the study across the wider population by collecting and collating a large number of data that will aid in generalising the findings. Furthermore, further researches are essential in a similar context with lecturers to counter-check lecturers' voices in a bid to provide a more balanced view.

\section{Data availability}

The data is not available for deposit due to confidentiality issues.

Received: 5 April 2020; Accepted: 22 September 2020;

Published online: 27 October 2020 


\section{References}

Abdulhamid TH, Shafiu MT, Murtala A (2017) Perpetuation Intention Of Using ELearning Among Universities Students In Nigeria. Int J Sci Technol Manag 6 (5):28-41

Aboderin OS (2011) The Status Information and Communication Technology (ICT) in Secondary Schools in Secondary Schools in Ondo State (Unpublished M Ed. Thesis).

Aboderin OS (2015) Challenges and prospects of e-learning at the National Open University of Nigeria. J Educ Learn 9(3):207-216

Aboderin OS, Kumuyi GJ (2013) The problems and prospects of e-learning in curriculum implementation in secondary schools in Ondo State, Nigeria. Int J Educ Res Technol 4(1):90-96

Adeola OS, Adewale OS, Alese BK (2013) Integrated E-Learning System (IES) for the Nigeria Universities: an architectural overview. Am J Database Theory Appl 2(1):1-8

Agostini L, Nosella A (2020) The adoption of Industry 4.0 technologies in SMEs: results of an international study. Manag Decision 58(4):625-643

Ahmed T (2010) E-learning as a new technological application in higher education and research: an empirical study and proposed model. Int Acad Res J 2:2-13

Ajadi TO, Salawu IO, Adeoyee FA (2008) E-learning and distance education in Nigeria. Turkish Online J Educ Technol 7(4):61-70

Al-Gahtani SS (2016) Empirical investigation of e-learning acceptance and assimilation: a structural equation model. Appl Comput Informat 12(1):27-50

Allen IE, Seaman J (2003) Sizing the opportunity: the quality and extent of online education in the United States, 2002 and 2003. the Sloan Consortium, Wellesley

Alshamaila Y, Papagiannidis S, Li F (2013) Cloud computing adoption by SMEs in the northeast of England: A multi-perspective framework. J Enterprise Inform Manag 26(3):250-275

Amedu IO, Sambo MH, Musa AJ, Onche EU (2014) Innovation in Teaching: Between Research and Classroom Practice. J Edu Prac 5(1):123-127

Andries P, Debackere K (2006) Adaptation in new technology-based ventures: Insights at the company level. Int J Manag Rev 8(2):91-112

Anene JN, Imam H, Odumuh T (2014) Problem and prospect e-learning in Nigerian Universities. Int J Technol Incl Educ 3(2):320-327

Anowor OO (2010) E-learning and Teacher Preparation in Nigeria, Being a Lead Paper Presented at the 2010 Annual Conference of the Faculty of Education. Nnamdi Azikiwe University, Awka

Arghya R, Pradip KB, Shilpee AD (2020) Psychological Analytics Based Technology Adoption Model for Effective Educational Marketing in Digital and Social Media Marketing, Emerging Applications and Theoretical Development. Springer, Switzerland, 2020

Asogwa CI (2011) The challenges of optimizing e-learning opportunities for effective education service delivery in the University of Nigeria Nsukka. In:Nkad O, Eze U (eds) Optimizing e-learning opportunities for effective education service delivery. Publication of Institute of Education University of Nigeria, Nsukka

Asongu SA, Le Roux S (2017) Enhancing ICT for inclusive human development in Sub-Saharan Africa. Technol Forecast Soc Change 118(C):44-54

Atsumbe BN, Emmanuel R, Igwe CO, Atsumbe J (2012) Repositioning vocational and technical education for effective manpower production in Nigeria. IOSR J Mech Civil Eng 1(4):01-06

Awa HO, Eze SC, Urieto JE, Inyang BJ (2011) The Upper Echelon Theory (UET): a major determinant of information technology adoption by SMEs in Nigeria. J Syst Inform Technol 15(6):278-295

Baker J (2012) The technology-organization-environment framework. Information Systems Theory. Springer

Bates Stephen R, Jenkin L (2007) Teaching and learning ontology and epistemology in political science. Polit Stud Assoc 27(1):55-63

Bhuasiri W, Xaymoungkhoun O, Zo H, Rho J (2012) Critical success factors for elearning in developing countries: a comparative analysis between ICT experts and faculty. Comput Educ 58(2):843-855

Bolland R, Tenkasi R (1995) Perspective making and perspective taking i communities of knowing. Organ sci 2:40-57

Boyatzis R (1998) Transforming qualitative information: thematic analysis and code development. Sage Publication Ltd, London

Braun V, Clarke V (2006) Using thematic analysis in psychology. Qual Res Psychol 3:77-101

Bukhari RA (2010) Information technology for E-learning in Developing countries. School of Business and Informatics. University of Boras, 1-85

Chau PY, Tam KY (1997) Factors affecting the adoption of open systems: an exploratory study. MIS Quarterly 12(1):1-24

Chiaha TU, Eze JU, Ezeudu FO (2013) Education students' Access to E-learning Facilities in Universities South-East of Nigeria. Informat Knowl Manag 3(10):32-33

Choudrie J, Dwivedi YK (2005) Investigating the research approaches for examining technology adoption issues. J Res Practice 1(1):1-12

Chuang TT, Nakatani K, Zhou D (2009) An exploratory study of the extent of information technology adoption in SMEs: an application of upper echelon theory. J Enterprise Inform Manag 22(1/2):183-196

Ciechanowski L, Przegalinska A, Magnuski M, Gloor P (2019) In the shades of the Uncanny Valley: an experimental study of human-Chatbot interaction. Future Generat Comput Syst 92:539-548
Daukilas S, Daiva V (2009) Factors influencing the development of E-learning technologies in Lithuanian countryside. Rural development 2009: 4th international scientific conference, 15-17 October, 2009, Akademija, Kaunas region, Lithuania: proceedings. Akademija: Lithuanian University of Agriculture, Vol. 4, b. 1 (2009). 304-310

Dubé J-P, Fang Z, Fong N, Luo X (2017) Competitive price targeting smartphone coupons. Market Sci 36(6):944-975

Economides N, Jeziorski P (2017) Mobile money in Tanzania. Market Sci 36(6):815-837

Elliot S, Loebbecke C (2000) Interactive, inter-organisational innovation in electronic commerce. Inform Technol People 13(1):46-66

Eze S, Duan Y, Chin H (2014) Examining emerging ICT's adoption in SMEs from a dynamic process approach. Inform Technol People 27(1):63-82

Eze SC, Awa H, Okoye J, Emecheta B, Anazodo R (2013) Determinant factors of Information communication technology (ICT) adoption by governmentowned universities in Nigeria: a qualitative approach. J Enterprise Inform Manag 26(4):427-443

Eze SC, Chinedu-Eze CV (2018) Examining information and communication technology (ICT) adoption in SMEs: a dynamic capabilities approach. J Enterprise Inform Manag 31(2):338-356

Eze SC, Chinedu-Eze V, Bello AO (2018) The utilisation of e-learning facilities in the educational delivery system of Nigeria: a study of M-University. Int J Educ Technol Higher Educ 15(34):1-20. https://doi.org/10.1186/s41239-018-0116-Z

Eze SC, Chinedu-Eze VC, Bello AO, Inegbedion H, Nwanji T, Asamu F (2019) Mobile marketing technology adoption in service SMEs: a multi-perspective framework. J Sci Technol Policy Manag 10(3):569-596. https://doi.org/ 10.1108/JSTPM-11-2018-0105

Falana FT (2015) Prospects and challenges of e-learning in Nigerian university education using national open university of Nigeria, Akure study centre, Akoko: Department of science and technical education (computer education unit) Adekunle Ajasin University Akungba Akoko

Fitzgerald B, Kenny T (eds) (2003) Open-source software in the trenches: Lessons from large-scale implementation. In: ST March, A Massey \& JI DeGross. Proceeding of the 24th International Conference on Information Systems (ICIS, 2003), Seattle, WA. The Association for Information Systems, 316-326

Franco M, Garcia M (2018) Drivers of ICT acceptance and Implementation in micro-firms in the estate agent sector: influence on organizational performance. Inform Techn Dev 24(4):658-680

Gangwar H, Date H, Ramaswamy R (2015) Understanding determinants of cloud computing adoption using an integrated TAM-TOE model. J Enterprise Inform Manag 28(1):107-130

Garrison DR, Anderson T (2003) E-Learning in the 21st century: a framework for research and practice. Routledge/Falmer, London

Gholami B, Kaviani F, Zabihi E (2009) Web 2.0, a boost in IT infrastructure flexibility and team collaboration. Second International conference on computer and electrical engineering. United Arab Emirates: IEEE Computer Society

Giola DA, Corley KG, Hamilton AL (2013) Seeking qualitative rigour in inductive research. Notes Gioia Methodol 16(1):15-31

Grandon EE, Pearson JM (2004) Electronic commerce adoption: an empirical study of small and medium US businesses. Infor Manag 42(1):197-216

Gutierrez A, Boukrami E, Lumsden R (2015) Technological, organisational and environmental factors are influencing managers' decision to adopt cloud computing in the UK. J Enterprise Inform Manag 28(6):788-807

Hong H, Hammad AWA, Sepasgozar S, Akbarnezhad A (2018) BIM adoption model for small and medium construction organisations in Australia, Engineering Construction and Architectural Management. https://doi.org/ 10.1108/ECAM-04-2017-0064

Hu PJ-H, Hui W (2012) Examining the role of learning engagement in technologymediated learning and its effects on learning effectiveness and satisfaction. Decision Support Syst 53(4):782-792

Ikediugwu N (2008) Challenges in information technology. In: Nwogu, BG (ed) Education in the information age: Global challenges and enhancement strategies. Nsukka. University Trust Publishers, pp. 355-349

Ilechukwu LC (2013) The assessment of utilization of e-learning opportunities for effective teaching and learning of religion in Nigerian tertiaryinstitutions. Euro J Edu Stud 5(3):343-359

Jimenez-jimeenez D, Sanz-valle R (2011) Innovation, Organizational learning and performance. J Bus Res 64(4):408-417

Johnson G, Scholes K, Whittington R (2008) Exploring Corporate Strategy: Text and Cases. 8th Edition, Prentice Hall, Harlow

Kajetanowtez, Wierzejewski (2010) Why Multinationals Contribute to ICT Education to Bridge the Digital Divide: Synergies Between Business Benefits and Socio-Economic Development in Emerging Economies, Master's Thesis, Erasmus University

Kayisire D, Wei J (2016) ICT adoption and usage in Africa: towards an efficiency assessment. Inform Technol Dev 22(4):630-653

Kizito BJ, Bijan K (2006) An Empirical Study on Education Strategy to E-learning in Developing Countries. Proceedings of 4th IEEE International Workshop on Technology for Education in Developing Countries (TEDC, 06). 
Kotler P (1984) Marketing essentials. Prentice-Hall, Englewood Cliffs

Lacey A, Luff D (2001) Trent focus for research and development in primary healthcare: An introduction to qualitative analysis. London: Trent Focus

Lee Y (2003) The technology acceptance model: past, present and future. Commun Assoc Inform Syst 12(50):752-780

Lian JW, Yen DC, Wang YT (2014) An exploratory study to understand theoretical factors affecting the decision to adopt cloud computing in Taiwan hospital. Int J Inform Manag 34(1):28-36

Liao J, Welsch H, Stoica M (2003) Organizational absorptive capacity and responsiveness: an empirical investigation of growth-oriented SMEs. Entrepreneurship Theory and Practice 28(1):63-85

Liverpool LSS, Marut MJ, Ndam JN, Oti DA (2010) Towards a model for elearning in Nigerian HEIs: lessons from the University of Jos. http:// asictresearch.wordpress.com/2010/05/21 (October 2, 2013)

Loogma K, Juri K, Meril U (2012) E-learning as innovation: Exploring innovativeness of the VET teachers' community in Estonia. Comput Edu 58(2):808-817

MacLennan L, Van Belle P (2014) Factors affecting organisational adoption of serviceoriented architecture (SOA). Inform Syst E-business Manag 12(1):71-100

Maduku DK, Mpinganjirab M, Duhca H (2016) Understanding mobile marketing adoption intention by South African SMEs: A multi-perspective framework. Int J Inf Manage 36:711-723

Maldonado U, Khan G, Moon J, Rho J (2011) E-learning motivation and educational portal acceptance in developing countries. Online Inform Rev 35(1):66-85

Markus M, Robey D (1998) Information technology and organizational change: causal structure in theory and research. Manag Sci 34(5):583-598

Markus ML, Tanis C (2000) The enterprise systems experience-from adoption to success. Framing the domains of IT research: Glimpsing the future through the past. Pinnaflex Educational Resources 173:207

Mason R, Rennie F (2006) E-Learning: The Key Concepts. Routlege, Abingdon Great Britain

Mehrtens J, Cragg PB, Mills AM (2001) A model of Internet adoption by SMEs. Inf Manag 39(3):165-176

Miles MB, Huberman AM (1994) Qualitative data analysis: an expanded sourcebook. Thousand Qaks. Sage Publication Ltd, California

Naidu S (2006) E-learning: a guide book of principles, procedures and practices. Common Wealth Education Media Centre for Asia, Asia

Napitupulu D, Syafrullah M, Rahim R, Abdullah D, Setiawan MI (2018) Analysis of user readiness toward ICT usage at small medium enterprise in South tangerang. J Phys 1007(1), https://doi.org/10.1088/1742-6596/1007/1/012042.

Naqvi SH (2007) Use of electronic resources of Jamia Millia Islamia (A Central University): a case study. NACLIN. pp. 320-324

Nbina JB, Obomanu BJ, Vikoo B(2011) Utilization of information and communication technology for quality instruction in rivers state university of education Port Harcourt. An assessment. J Emer Trends Educ Res Policy Stud 2:74-80

Nguyen TH (2009) Information technology adoption in SMEs: an integrated framework. Int J Entrepre Behav Res 15(2):162-186

Nguyen TH, Newby M, Macaulay MJ (2015) Information Technology Adoption in Small Business: Confirmation of a Proposed Framework. J Small Bus Manag 53(1):207-227

Nkanga E (2007) The Rise of E-learning in Country. Accessed 22nd April, 2012. www.allafrian.com/stories/20070802014.htm/.

Nuryyev G, Wang Y-P, Achyldurdyyeva J, Jaw B-S, Yeh Y-S, Lin H-T, Wu L-F (2020) Blockchain technology adoption behaviour and sustainability of the business in tourism and hospitality SMEs: an empirical study. Sustainability 12(3):12-56. https://doi.org/10.3390/su12031256

Nwokolo AA, Anyachebelu EF (2012) Availability and use of information and communication technology resources for counselling university students in South East States. Nigerian Int J Human Soc Sci 2(7):220-225

Nwokolo SA, Allu S, Rabiu GM (2017) A review of E-learning technologies adoption in Nigeria's tertiary education institutions. J Eng Sci Technol 1(1):67-71

Oguzor NS (2011) E-learning technologies and adult education in Nigeria. Educ Res Rev 6(4):347-349

Okundaye K, Fan SK, Dwyer RJ (2019) Impact of information and communication technology in Nigeria small to medium-sized enterprises. J Econ Finance Admin Sci 24:29-46. https://doi.org/10.1108/JEFAS-08-2018-0086

Oliveira T, Martins MF (2011) Literature review of information technology adoption models at the firm level. Electron J Inf Sys Eval 14:110-121

Olojo OJ, Adewumi MG, Ajisola KT (2012) E-learning and its effects on teaching and learning in a global age. Int J Acad Re Bus Soc Sci 2(1):203-210

Ololube NP, Udogu AE, Ossai AG (2006) ICT and distance education in Nigeria: a review of literature and accounts. February, 15, 2011. http://www.educause. edu/librarydetailpage/6668andID-PUB8001.

Orlikowski JW, Baroudi JJ (1991) Studying Information Technology in Organizations: Research Approaches and Assumptions. Inf Sys Res 2(1):1-28

Ostund B (2005) Stress Disruption and Community Adult Learner's Experience of Obstacles and Opportunities in Distance Education. European Journal of open Distance and E-learning (Euro DL). 2005. www.eurodol.org.material/ briefstand-GBA.html.
Pineda-Herrero P, Carla Q, Alexandra S (2011) Evaluating the efficacy of elearning in Spain: a diagnosis of learning transfer factors affecting e-learning. Procedia - Social and Behavioral Sciences 30(1):2199-2203

PR Newswire (2019) Global Social Media Analytics Industry, Forecast to 2024-High Adoption Rate of Social Media Analytics Solutions SMEs. Regional Business News

Prause M (2019) Challenges of industry 4.0 technology adoption for SMEs: the case of Japan. Sustainability 11(20):5807

Ramdani B, Kawalek P (2008) Exploring SMEs' adoption of broadband in the Northwest of England. In Handbook of Research on Global Diffusion of BroadbandData Transmission. 504-523

Ruivo P, Oliveira T, Neto M (2014) Examine ERP post-implementation stages of use and value: empirical evidence from Portuguese SMEs. Int J Account Inf Syst 15(2):166-184

Schultze U, Avital M (2011) Designing Interviews to Generate Rich Data for Information Systems Research. Inf Organ 21(1):1-16

Silva L (2007) Post-positivist review of technology acceptance model. J Assoc Inform Syst 8(4):255-266

Singh G, Hardaker G (2014) Barriers and enablers to adoption and diffusion of elearning. Educ Training 56(2/3):105-121

Sloan D, Porter E, Robins K, McCourt K (2014) Using E-learning to Support International Students' Dissertation Preparation 56(2/3):122-140

Song H (2003) E-service at FedEx. Communication of the ACM 46(6):45-46

Thong JY (1999) An integrated model of information systems adoption in small businesses. J Manag Inf Sys 15(4):187-214

To, ML, Ngai, EW (2006) Predicting the organisational adoption of B2C e-commerce: an empirical study. Ind Manag Data Sys106(8):1133-1147

Tornatzky L, Fleischer M (1990) The Process of Technology Innovation. Lexington Books, Lexington, MA

Wang T (2009) Rethinking teaching with information and communication technologies (ICTs) in architectural education. Teaching Teacher Educ 25(8):1132-1140

Weng M-H, Lin C-Y (2011) Determinants of green innovation adoption for small and medium-size enterprises (SMES). Afr J Bus Manag 5(22):9154-9163

Xu H, Dinev T, Smith J, Hart P (2011) Information Privacy Concerns: Linking Individual Perceptions with Institutional Privacy Assurances. J Assoc Inf Sys 12(12):1 https://doi.org/10.17705/1jais.00281

Zafar A, Mustafa S (2017) "SMEs and its role in economic and socio-economic development of Pakistan". Int J Acad Res Account Finance Manag Sci 7(4):195-205

Zhang Q, Cheng L, Boutaba R (2010) Cloud computing: state-of-the-art and research challenges. J Internet Services Appl 1(1):7-18

Zhu K, Kraemer K, Xu S (2003) Electronic business adoption by Europe firms: A crosscountry assessment of the facilitators and inhibitors. Eur J Inf Syst 12(4):251-256

\section{Author contributions}

All the authors greatly contributed in designing, analysis or interpretation. They were also involved in drafting, revising the paper. Collectively they agreed on the final version to be published and agreed to be accountable for all the aspects of the work.

\section{Competing interests}

The authors declare no competing interests.

\section{Additional information}

Correspondence and requests for materials should be addressed to S.C.E.

Reprints and permission information is available at http://www.nature.com/reprints

Publisher's note Springer Nature remains neutral with regard to jurisdictional claims in published maps and institutional affiliations.

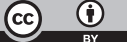

Open Access This article is licensed under a Creative Commons Attribution 4.0 International License, which permits use, sharing, adaptation, distribution and reproduction in any medium or format, as long as you give appropriate credit to the original author(s) and the source, provide a link to the Creative Commons license, and indicate if changes were made. The images or other third party material in this article are included in the article's Creative Commons license, unless indicated otherwise in a credit line to the material. If material is not included in the article's Creative Commons license and your intended use is not permitted by statutory regulation or exceeds the permitted use, you will need to obtain permission directly from the copyright holder. To view a copy of this license, visit http://creativecommons.org/ licenses/by/4.0/.

(C) The Author(s) 2020 